\title{
EFFECT OF FISH OIL REPLACEMENT WITH SOYBEAN OIL ON GROWTH PERFORMANCE, IMMUNE RESPONSE,BIOCHEMICAL ANDHEMATOLOGICAL PARAMETERSOF NILE TILAPIA
}

\author{
Eldsokey Nassef ${ }^{1 *}$, Ahmed Sherif ${ }^{2}$, Tarek Abuzed ${ }^{3}$
}

1 Nutrition and Clinical Nutrition Department, Faculty of Veterinary Medicine, Kafrelsheikh University, 33516 Kafrelsheikh, Egypt

${ }^{2}$ Agriculture Research Center, Animal Health Research Institute, Kafrelsheikh, Egypt

3 Biochemistry Department, Faculty of Veterinary Medicine, Kafrelsheikh University, 33516 Kafrelsheikh, Egypt

Corresponding author: dsokeynassef@yahoo.com; 01009665583

\section{ABSTRACT}

The study aimed to investigate the effect of fish oil (FO) replacement with soybean oil (SO)on growth performance, biochemical and hematological parameters, and immune response of Nile tilapia. Ninety fish, weighed $20.1 \pm 0.2 \mathrm{~g}$, was assigned into 3 groups (3 replicates each). Three dietary treatments contained FO (5\%), SO (5\%) or an equal mix(2.5+2.5\%) offish and soybean oils (FSO).The fish was fed on iso-caloric (3147 Kcal/kg) and iso-nitrogenous (30.62\% crude protein) diets. The experiment lasted for 8 weeks. The average daily gain of fish fed FO was the greatest $(0.61 \pm 0.03 g)$ followed by FSO $(0.56 \pm 0.01 \mathrm{~g})$ then SO $(0.54 \pm 0.01 \mathrm{~g})$. Also, FO significantly improved feed conversion ratio (1.66 \pm 0.04$)$ as compared with SO (1.82 \pm 0.02$)$ or FSO (1.78 \pm 0.07$)$. FO significantly stimulated feed intake as compared to SO. FO significantly increased ash and decreased fat contents in the carcass. A significant increase in the number of red blood cells, packed cell volume and hemoglobin concentration was achieved in the group fed FO than those fed on SO or FSO. However, SO increased heterophils and decreased 
lymphocytes as compared with FO and FSO. Also, serum protein was significantly increased in fish fed FO than the other two groups. FO significantly decreased serum triglycerides, cholesterol, and creatinine than the other two groups. Moreover, FO significantly increased serum antibacterial activity (48.5\%) than SO (44.4\%) or FSO (45.8\%). It could be concluded that the complete replacement of FO with SO decreased growth performance and feed utilization of the Nile tilapia. However, FSO could be practically utilized in fish diets without a harmful effect on the growth performance of Nile tilapia fish.

Keywords: Oils,Nile tilapia, growth performance,Biochemical, Hematological parameters

\section{INTRODUCTION}

Fish oil (FO) is the main lipid source used in the formulation of commercial aquafeeds (NRC, 2011). However, the decreasing availability and high price have enforced research activities to evaluate alternative lipid sources (Food and Agriculture Organization, 2010). Soybean oil (SO)is regarded as a valuable lipid source with economical price and wide availability (Turchini et al. 2009). Despite the fact that SO devoid of the n-3 long-chain polyunsaturated fatty acids, NRC (2011) has demonstrated that Nile tilapia requires only linoleic fatty acid (n-6) by $1 \%$ of the diet. Fish meals (FM) are an essential part of diet composition in tilapia as a source of protein and n-3 fatty acids (NRC, 2011). Nowadays, aquaculture is suffering from low availability and the high cost of FM.

Crude fat is an important source of essential fatty acids for the regular growth and health of fish (Turchini et al. 2009). The optimum dietary fat levels are ranging from 5- 12\% in diets for tilapia (Craig et 
al., 2017). Due to the development of aquaculture, it is predictable that the requirement of FM and FO will increase. But, there are difficulties with the high cost and limiting the availability of FM and FO (Food and Agriculture Organization 2010).

It is assumed that SO could replace FO due to its economical price and wide availability (Turchini et al. 2009). SO can be included in fish diets at different levels of FO substitution. But the alterations in the sources of dietary fat can affect fish health. Fat modulates the physical properties of immune cell membranes, eicosanoidsand receptor sites (Montero et al., 2004). Some studies demonstrated that using vegetable oil in the tilapia diet has no influence on growth performance (Han et al. 2013; $N g$ et al. 2013). They revealed that Nile tilapia could grow well with vegetable oils. Another study showed that using vegetable oil decreases the growth of the fish (Szabo et al. 2011) and suppress immunity. Therefore, the objective of this study was to investigate the effect of the half and complete replacement of FO with SOon growth performance, biochemicaland hematological parameters, and immune response of Nile tilapia.

\section{MATERIAL AND METHODS}

\subsection{Fish and diets}

One hundred and twenty fingerlings of Nile Tilapia were purchased from a commercial farm in Kafrelsheikh governorate and were adapted to tank conditions for 2 weeks. Ninetyfish of homogenous size (20.1 \pm 0.2$)$ were selected and randomly distributed into 3 groups (3 
replicates each). Each replicate contained 10 fish per tank of 50-L which was equipped with continuous aeration.

Three experimental diets were formulated (Table 1) containing FO, SO and FSO. The diets were practically similar in energy and protein (Table 2). The ingredients were finely ground (2 mm) and mixed for 15 min. The oil was slowly added with continuous mixing. Distilled water was slowly added to the diets till forming a soft dough. Carboxy methyl cellulose $(0.2 \%)$ was used as a binder to facilitate pelletization. The diets were pelleted in a laboratory pellet mill through a $2 \mathrm{~mm}$ diameter die. Pellets were dried in an oven at $60{ }^{\circ} \mathrm{C}$ for $2 \mathrm{~h}$ and freshly used. The experimental period lasted for 8 weeks. The fish were fed twice daily at 8.00 and $15.00 \mathrm{~h}$ at a level of $4 \%$ of body weight. Feed refusal was recovered after feeding and dried using the oven at $60{ }^{\circ} \mathrm{C}$ for $2 \mathrm{~h}$ then subtracted from the offered feed.

Table (1): Ingredients composition(\%)of the experimental diets for Nile tilapia

\begin{tabular}{|c|c|c|c|}
\hline \multirow{2}{*}{ Items } & \multicolumn{3}{|c|}{ Dietary treatments } \\
\hline & Fish oil & Soybean oil & Fish \& soybean oils \\
\hline Corn gluten meal (60\%) & 7.0 & 7.0 & 7.0 \\
\hline Soybean oil (refined) & 0.0 & 5.0 & 2.5 \\
\hline Fish oil & 5.0 & 0.0 & 2.5 \\
\hline Corn grain & 33.0 & 33.0 & 33.0 \\
\hline Dehulled soybean meal (48\%) & 51.6 & 51.6 & 51.6 \\
\hline Monocalcium phosphate & 1.58 & 1.58 & 1.58 \\
\hline Limestone & 0.67 & 0.67 & 0.67 \\
\hline Salt & 0.30 & 0.30 & 0.30 \\
\hline Methionine, DL & 0.25 & 0.25 & 0.25 \\
\hline Premix $^{\mathrm{a}}$ & 0.1 & 0.1 & 0.1 \\
\hline Anti-mycotoxin & 0.2 & 0.2 & 0.2 \\
\hline Vitamin C (protected) & 0.1 & 0.1 & 0.1 \\
\hline
\end{tabular}

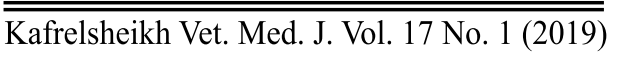




\begin{tabular}{||l||c||c||c||}
\hline Binder (carboxy methyl ellulose) & 0.2 & 0.2 & 0.2 \\
\hline
\end{tabular}

aPremix provides Manganese 20mg ; Zinc100mg ; Iron 30mg ; Copper $5 \mathrm{mg}$; Iodine $5 \mathrm{mg}$; Cobalt $0.01 \mathrm{mg}$;Selenium 0.1mg; vit A 5500 UI; vit D3 1000 UI; vit E 50 mg; vit B1 5 mg ; vit B2 10 mg ; vit B6 20mg ; vit B12 0.02 mg ; niacin 100mg; vit K3 10mg ; biotin $0.1 \mathrm{mg}$; folic acid $5 \mathrm{mg}$ per kg diet.

Table (2): Chemical composition of the experimental diets

\begin{tabular}{|c|c|c|c|}
\hline \multirow{2}{*}{ Items } & \multicolumn{3}{|c|}{ Dietary treatments } \\
\hline & Fish oil & Soybean oil & Fish \& soybean oils \\
\hline Digestible energy ${ }^{\mathrm{a}}$, Kcal $/ \mathrm{kg}$ & 3158 & 3136 & 3147 \\
\hline Crude protein \% & 32.23 & 32.23 & 32.23 \\
\hline Lysine \% & 1.71 & 1.71 & 1.71 \\
\hline Methionine \% & 0.75 & 0.75 & 0.75 \\
\hline Crude fat \% & 6.93 & 6.93 & 6.93 \\
\hline Calcium \% & 0.7 & 0.7 & 0.7 \\
\hline Available phosphorus \% & 0.45 & 0.45 & 0.45 \\
\hline
\end{tabular}

${ }^{\mathrm{b}}$ Calculated according to equations of digestible energy in NRC (2011).

\subsection{Growth performance}

After 2 weeks of adaptation, the fish was weighed individually to determine initial body weight. Thereafter, the fish was weighed regularly every 2 weeks to calculate body weight gain, $(\mathrm{BWG})=$ Final BWT (g)Initial BWT (g), and average daily gain (ADG)= BWG (g)/duration of the experiment (56 days). Feed intake (FI) was recorded daily then cumulated for 2 weeks and along with the experiment. Feed conversion ratio (FCR) was calculated as follow: FCR=Feed intake (g)/BWG (g).

\subsection{Chemical analysis of the diets and fish:}

Feed samples were ground through a 1mm screen (Cyclotec, Foss Sweden). The procedures of feed analysis wereaccording to AOAC (2010). The ground samples were analyzed for crude protein (Kjeldahl method) and ether extract (Ankom Technology method). Nitrogen-free 
extract (NFE) was calculated as follow: NFE= 100- (moisture + crude protein + ether extract + ash + crude fiber). Calcium, available phosphorus,lysine, and methionine were calculated based on values of feed composition in tables of $N R C(2011)$.

Three fish were randomly collected from each tank at the end of the experiment for chemical analysis. The fish was dried in the oven at $60{ }^{\circ} \mathrm{C}$ for 48 h. Dry matter and moisture were determined. The dried samples were ground and analyzed for crude protein, ether extract, ash according to $A O A C$ (2010).

\subsection{Hematological and biochemical analyses:}

Blood sampleswere collected from 5 fish per tank at the end of the experiment. The sample was collectedfrom the caudal vein into a heparinized tube for analysis of the complete blood picture. A further blood sample was collected, centrifuged at $3000 \mathrm{rpm}$ for $10 \mathrm{~min}$ to separate the serum. The serumwas stored at $-20{ }^{\circ} \mathrm{C}$ until the biochemical analysis. Hematocrit, red blood cells (RBCs), white blood cells (WBCs) and hemoglobin (HB) were determined by the methods described by Campbell et al., (1990). Blood film was prepared according to the method described by Lucky (1977). Differential leukocyte count was calculated according to Schalm (1986).

The concentration of serum total protein and albumin were measured by colorimetric methodsaccording to (Doumas et al., 1971). Serum globulin concentration was determined by subtracting the concentration of albumin from total protein. The activity of the liver 
enzymes, alanine aminotransaminase (ALT) and aspartate amino transaminase (AST) were determined according to (Reitman and Frankel, 1957). Colorimetric estimation of cholesterol triacylglycerol, HDL and LDL was done as previously described by (Tietz, 1995).

\subsection{Serum antibacterial test:}

Serum bactericidal test was performedaccording to the method of Kajita et al. (1990). Equal volumes $(100 \mu l)$ of serum and A. hydrophila bacterial suspension $2 \times 10^{8}$ (CFU) were mixed and incubated for $1 \mathrm{~h}$ at 25 ${ }^{\circ} \mathrm{C}$. Blank control was also prepared by replacing serum with sterile phosphate buffer saline (PBS). The blend was diluted with sterile PBS at a ratio of 1:10. The diluted blend $(100 \mu l)$ was plated on blood agar and incubated at $37{ }^{\circ} \mathrm{C}$ for $24 \mathrm{~h}$. The number of viable bacteria was determined by counting the colonies grown on the agar plates.

\subsection{Statistical analysis:}

Statistical analysis was performed usingthe SPSS program (SPSS, 2004). The data was exposed to normal distribution before the analysis of variance (ANOVA). Duncan's multiple ranges (Duncan, 1955) was used to determine the significant difference amongmeans at $\mathrm{P}<0.05$.

\section{RESULTS}

The results of the growth performance are shown in Table 3. The results showed that the final weight was significantly higher in fish fed FO than those fed the other diets. Also, fish fed FO had significantly higher BWG and ADG than those fed SO. But, BWG of fish fed FSO didn't significantly differ from the other groups. ADG of fish fed FO was 
the greatest $(0.61 \pm 0.03 g)$ followed by FSO $(0.56 \pm 0.01 \mathrm{~g})$ then SO $(0.54 \pm 0.01 \mathrm{~g})$. Feed intake of fish fed FO was significantly higher than those fed the other diets. Similarly, FCR was significantly improved in fish fed FO compared to the other diets which showed no significant difference in between.

Table (3): Effect of fish oil replacement with soybean oil on growth performance of Nile tilapia fish

\begin{tabular}{|c|c|c|c|}
\hline \multirow{2}{*}{ Items } & \multicolumn{3}{|c|}{ Dietary treatments } \\
\hline & Fish oil & Soybean oil & Fish \& soybean oils \\
\hline Initial weight (g) & $20.13 \pm 0.17$ & $20.3 \pm 0.17$ & $20.07 \pm 0.02$ \\
\hline Final weight (g) & $54.53 \pm 0.96^{\mathrm{a}}$ & $50.27 \pm 3.1^{\mathrm{b}}$ & $51.1 \pm 2.8^{b}$ \\
\hline Body weight gain (g) & $34.4 \pm 0.88^{\mathrm{a}}$ & $29.97 \pm 1.09^{b}$ & $31.06 \pm 1.86^{\mathrm{ab}}$ \\
\hline Average daily gain (g) & $0.61 \pm 0.03^{\text {a }}$ & $0.54 \pm 0.01^{\text {c }}$ & $0.56 \pm 0.01^{b}$ \\
\hline Feed intake (g) & $57.16 \pm 0.2^{\mathrm{a}}$ & $54.4 \pm 0.6^{\mathrm{b}}$ & $55.2 \pm 0.9^{b}$ \\
\hline Feed conversion ratio & $1.66 \pm 0.04^{\mathrm{b}}$ & $1.82 \pm 0.02^{\mathrm{a}}$ & $1.78 \pm 0.07^{\mathrm{a}}$ \\
\hline
\end{tabular}

Means \pm SE with a different letter are significantly different at $\mathrm{P}<0.05$.

Data of carcass chemical composition are presented in Table 4. There were no significant differences between different groups in moisture, dry matter, and crude protein. Feeding FO significantly increased mineral concentration in the skeleton as compared to $\mathrm{SO}$ or FSO.WhileFO decreased the fat content in the body of Nile tilapia fish when compared to SO or FSO. 
Hematological parameters were illustrated in Table 5. Feeding FO increased RBCs count as compared to SO or FSO. Also, feeding FO increased $\mathrm{HB}$ and PCV concentrations than the other groups. On the other hand, SO reduced WBC count than the other groups. However, SO raised heterophil and reduced lymphocyte numbers than the other groups. Other blood cells (eosinophil, monocytes, and basophil) still unchanged among the dietary treatments.

Table (4): Effect of fish oil replacement with soybean oil on carcass chemical composition of Nile tilapia fish (on dry matter basis)

\begin{tabular}{|c|c|c|c|}
\hline \multirow{2}{*}{ Items \% } & \multicolumn{3}{|c|}{ Dietary treatments } \\
\hline & Fish oil & Soybean oil & Fish \& soybean oils \\
\hline Dry matter & $25.53 \pm 0.56$ & $26.07 \pm 0.88$ & $26.11 \pm 0.29$ \\
\hline Moisture & $74.47 \pm 0.58$ & $73.93 \pm 0.88$ & $73.89 \pm 0.29$ \\
\hline Crude protein & $54.62 \pm 0.15$ & $54.78 \pm 0.11$ & $54.59 \pm 1.7$ \\
\hline Ether extract & $21.36 \pm 0.95^{\mathrm{b}}$ & $23.32 \pm 0.1^{\mathrm{a}}$ & $22.63 \pm 0.8^{\mathrm{a}}$ \\
\hline Ash & $20.0 \pm 1.48^{\mathrm{a}}$ & $16.8 \pm 0.28^{c}$ & $18.35 \pm 1.4^{b}$ \\
\hline Carbohydrate & $4.02 \pm 0.37$ & $5.1 \pm 0.36$ & $4.43 \pm 0.35$ \\
\hline
\end{tabular}

Means \pm SE with a different letter are significantly different at $\mathrm{P}<0.05$.

Table (5): Effect of fish oil replacement with soybean oil on hematological parameters of Nile tilapia

\begin{tabular}{|c|c|c|c|}
\hline \multirow{2}{*}{ Items } & \multicolumn{3}{|c|}{ Dietary treatments } \\
\hline & Fish oil & Soybean oil & Fish \& soybean oils \\
\hline $\mathrm{RBCS} * 10^{6} / \mathrm{mm}^{3}$ & $2.71 \pm 0.04^{\mathrm{a}}$ & $1.98 \pm 0.06^{\mathrm{b}}$ & $2.12 \pm 0.03^{b}$ \\
\hline TLC* $10^{3} / \mathrm{ml}$ & $128.32 \pm 0.2^{\mathrm{a}}$ & $122.42 \pm 1.3^{\mathrm{b}}$ & $125.26 \pm 0.6^{\mathrm{a}}$ \\
\hline
\end{tabular}

Kafrelsheikh Vet. Med. J. Vol. 17 No. 1 (2019) 


\begin{tabular}{|c|c|c|c|}
\hline Heterophil* $10^{3} / \mathrm{ml}$ & $26.32 \pm 0.5^{b}$ & $31.58 \pm 0.5^{\mathrm{a}}$ & $27.68 \pm 0.5^{b}$ \\
\hline Monocyte* $10^{3} / \mathrm{ml}$ & $4.95 \pm 0.2$ & $5.2 \pm 0.6$ & $4.7 \pm 0.9$ \\
\hline Lymphocyte* $10^{3} / \mathrm{ml}$ & $65.6 \pm 0.3^{\mathrm{a}}$ & $59.6 \pm 0.6^{\mathrm{b}}$ & $64.6 \pm 1.1^{\mathrm{a}}$ \\
\hline Eosinophil $* 10^{3} / \mathrm{ml}$ & $3.8 \pm 0.3$ & $4.0 \pm 0.6$ & $4.2 \pm 0.6$ \\
\hline Basophil*103/ml & $0.40 \pm 0.03$ & $0.41 \pm 0.03$ & $0.38 \pm 0.03$ \\
\hline Hemoglobin (g/dl) & $9.16 \pm 0.21^{\mathrm{a}}$ & $7.01 \pm 0.05^{b}$ & $7.52 \pm 0.09^{b}$ \\
\hline PCV (\%) & $27.47 \pm 0.8^{\mathrm{a}}$ & $22.11 \pm 0.03^{b}$ & $23.26 \pm 0.4^{b}$ \\
\hline
\end{tabular}

RBCS, red blood corpuscles; TLC, total leukocytes count; PCV, packed cell volume. Means \pm SE with a different letter are significantly different at $\mathrm{P}<0.05$.

The results of the biochemical parameters are shown in Table 6 . Liver enzymes (ALT and AST) were significantly lower in fish fed FO than those fed SO. However, the values of ALT and AST of all groups were within the acceptable range. The same criteria were recorded in creatinine analysis.Serum total protein and globulin weresignificantly high in fish fed FO. The serum albumin was nearly similar among all groups.Serum triglyceride and cholesterol were significantly lower in fish fed FO as compared to SO or FSO groups. Feeding FO decreased LDL and increased HDL than the other two groups. On the other hand, fish fed FSO had a lower LDL and a higher HDL than the SO group.The serum antibacterial test of different groups is presented in Table 6. The result indicated a significant enhancement of the immune status of group fed FO but differences with other groups were in an acceptable range which showed no threat to fish life.

Table (6): Effect of fish oil replacement with soybean oil on biochemical parameters and serum antibacterial activity of Nile tilapia fish

\begin{tabular}{|l||c|c||c|}
\hline \multirow{2}{*}{ Items } & \multicolumn{3}{|c|}{ Dietary treatments } \\
\cline { 2 - 4 } & Fish oil & Soybean oil & Fish \& soybean oils \\
\hline
\end{tabular}

Kafrelsheikh Vet. Med. J. Vol. 17 No. 1 (2019) 


\begin{tabular}{||c||c||c||c||}
\hline \hline ALT (u/l) & $33.61 \pm 1.2^{\mathrm{c}}$ & $46.35 \pm 0.8^{\mathrm{a}}$ & $40.38 \pm 0.7^{\mathrm{b}}$ \\
\cline { 2 - 3 } & $104.2 \pm 2.46^{\mathrm{b}}$ & $127.4 \pm 5.4^{\mathrm{a}}$ & $110.3 \pm 1.1^{\mathrm{b}}$ \\
\hline AST (u/l) & $0.84 \pm 0.04^{\mathrm{c}}$ & $1.81 \pm 0.13^{\mathrm{a}}$ & $1.42 \pm 0.08^{\mathrm{b}}$ \\
\hline Creatinine (mg/dl) & $6.8 \pm 0.14^{\mathrm{a}}$ & $5.5 \pm 0.02^{\mathrm{b}}$ & $5.9 \pm 0.1^{\mathrm{b}}$ \\
\hline Total protein (g/dl) & $4.2 \pm 0.05$ & $4.1 \pm 0.02$ & $4.17 \pm 0.02$ \\
\hline Albumin (g/dl) & $2.6 \pm 0.15^{\mathrm{a}}$ & $1.4 \pm 1^{\mathrm{b}}$ & $1.73 \pm 0.3^{\mathrm{b}}$ \\
\hline Globulin (g/dl) & $2.6 \pm 1.4 \pm 5^{\mathrm{b}}$ \\
\hline Triglycerides (mg/dl) & $144.4 \pm 1.9^{\mathrm{c}}$ & $297.2 \pm 2^{\mathrm{a}}$ & $290.4 \pm 1.5^{\mathrm{a}}$ \\
\hline Cholesterol (mg/dl) & $97.5 \pm 1.5^{\mathrm{b}}$ & $122.5 \pm 2.3^{\mathrm{a}}$ & $117.2 \pm 0.6^{\mathrm{a}}$ \\
\hline HDL (mg/dl) & $57.2 \pm 0.8^{\mathrm{a}}$ & $49.6 \pm 0.5^{\mathrm{c}}$ & $52.3 \pm 0.8^{\mathrm{b}}$ \\
\hline LDL (mg/dl) & $2.87 \pm 0.3^{\mathrm{c}}$ & $20 \pm 0.8^{\mathrm{a}}$ & $11.5 \pm 3.3^{\mathrm{b}}$ \\
\hline SAA (\%) & $48.5 \pm 0.6^{\mathrm{a}}$ & $44.4 \pm 0.7^{\mathrm{b}}$ & $45.8 \pm 0.3^{\mathrm{b}}$ \\
\hline
\end{tabular}

Means \pm SE with a different letter are significantly different at $\mathrm{P}<0.05$. ALT, alanine aminotransferase; AST, aspartate aminotransferase; HDL, high-density lipoprotein; LDL, low-density lipoprotein; SAA, serum antibacterial activity.

\section{DISCUSSION}

The results showed that the group fed a diet containingFO had significant high growth performance than those fed SO. Similarly, Szabo' et al. (2011) who had used 6\% SO in the replacement of FO. In contrast, Han et al. (2013) had used 4.5\% SO in the replacement of FO in hybrid tilapia diets and found that all groups had similar final body weight. Our results showed a beneficial effect of using a mixture of FSO on growth performance. Also, $\mathbf{N g}$ et al. (2013) investigated a mixture of SO and FO (1:1) in the replacement of FO in red hybrid tilapia diets and detected no significant difference in the growth performance. The contradictory results of the growth performance might be due to the differences of hybrid of tilapia, based formulation, dietary lipid level and duration of the growth trial. Previous studies had used FM in the experimental diets which are considered a source of FO. In the present study, we excluded FMfrom the diets to avoid conflicting of the results. 
This study showed that fish fed FO had significantly lower carcass fat content than the other groups. This might be due to the high phospholipid content of FO than the SO. Phospholipidsare reported to inhibit fat accumulation in the liver and viscera (Peng et al., 2016). A similar finding was reported by Guler and Yildiz (2011) in rainbow trout fish. Fish fed FO had higher carcass ash content than the other groups. The relation between the type of oil and mineral metabolism in fish is less investigated. In some studies on European sea bass, Villeneuve et al., (2006) demonstrated that FO supported skeletal growth without deformities. On the other hand, arachidonic acid derived from SO is a potent stimulator of bone resorption (Watkins et al. 2001).

Feeding FO enhanced the health condition of Nile tilapia as showed by increasing RBCs count, $\mathrm{HB}$ concentration and PCV. These resultsmight explain the positive effect of FO on growth performance. Blood cells reflect dietary changes due to their fast regeneration. FO is rich in phospholipids which maintain osmotic pressure and nutrient transport across the cell membrane of RBCs. On the other hand, feeding SO to channel catfish increased erythrocyte fragility (Klinger et al., 1996). Vegetable oils (blend of rapeseed and linseed oils) reduced hematocrit and red blood cell counts in salmon fish (Bell et al., 2003).

Feeding FO increased TLC than the other groups. Fish fed SO had high heterophil and low lymphocyte count than those fed FO or FSO. In contrast, the previous reports documented that FO decreased lymphocyte proliferation (Calder, 2006). Also, He reported that SO stimulatedlymphocyte replication. The contradictions found in the literature concerning the effect of lipid on TLC differentiation might be due to fish species, lipid level, and the presence of antioxidants. 
The current results revealed that feeding FO or a blend of FSO enhanced liver function as indicated by reducing serum ALT level than fish fed SO. This may be due to the effect on the histological structure of the liver (Apraku et al., 2019). Elevating SO increased fat deposition in hepatocyte leading to metabolic imbalance.SO had a lipogenic effect and lowered the antioxidant capacity of fish (Riera-Heredia et al., 2019).

The result of the serum antibacterial test indicated that the group fed FO had significant enhancement of the immune response of fish over the other groups. Partial replacement of FO by SO affected non-specific immune response in fish ( $\mathbf{M u}$ et al., 2018). Overall, Nile tilapia may require FO to ensure fish health, stress resistance, and immune response.

\section{CONCLUSION}

In conclusion, the complete replacement of FO with SO decreased growth performance and feed utilization of the Nile tilapia. Dietary inclusion of FO is important for the general health condition and immune response of Nile tilapia. Finally, FSO could be practically utilized in fish diets without adverse effect on the growth performance.

\section{REFERENCES}

- AOAC., 2010. Official methods of analysis $16^{\text {th }}$ edition Association of Official Analytical Chemists. Arlington, VA.

- Apraku, A., Huang, X., Yusuf, A., Cornel, A., Ayisi, C.L. and Asiedu, B., 2019. Impact of dietary oil replacement on muscle and liver enzymes activity, histomorphology and growth-related genes on Nile tilapia. Comparative Biochemistry and Physiology Part C: Toxicology \& Pharmacology, 223, pp.15-25. 
- Bell, J, McGhee F, Campbell P, Sargent J.,2003. Rapeseed oil as an alternative to marine fish oil in diets of post-smolt Atlantic salmon (Salmo salar): changes in flesh fatty acid composition and effectiveness of subsequent fish oil "wash out." Aquaculture; 218:515-28.

- Calder P., 2006. Polyunsaturated fatty acids and inflammation. Prostaglandins Leukotrienes Essential Fatty Acids; 75: 197-202.

- Campbell, T. and Murru, F., 1990. An introduction to fish hematology. Compendium on Continuing Education for the Practicing Veterinarian, 12(4), pp.525-532. Craig, S., Helfrich, L.A., Kuhn, D. and Schwarz, M.H., 2017. Understanding fish nutrition, feeds, and feeding.

- Doumas B, Waston W, Biggs H.,1971. Albumin standards and measurements of serum albumin with Bromocresol Green. Clinica Chimica Acta; 31: 87-96.

- Duncan, D.B. (1955): Multiple ranges and multiple "F" test. Biometrics, 11:10.

- Guler, M, Yildiz M., 2011. Effects of dietary fish oil replacement by cottonseed oil on growth performance and fatty acid composition of rainbow trout (Oncorhynchus mykiss). Turk J Vet Animal Science; 35 (3):157-67.

- Han C, Zheng Q, Feng L., 2013. Effects of total replacement of dietary fish oil on growth performance and fatty acid compositions of hybrid tilapia (Oreochromis niloticus 9 O.aureus). Aquaculture International 21:1209-17. 
- Kajita Y, Sakai M, Atsuta S, Kobayashi M., 1990. The immunostimulatory effects of levamisole onrainbow trout, Oncorhynchus mykiss. Fish Pathology1990; 25: 93-8.

- Klinger R, Blazer V, Echevarria C., 1996. Effects of dietary lipid on the hematology of channel catfish, Ictalurus punctatus. Aquaculture; $147,225-33$.

- Lucky, Z. (1977). Methods for Diagnosis of Fish Disease. Amerind Publishing Co. New York.

- Montero D, Socorro J, Tort L, Caballero M, Robaina L, Vergara J, Izquierdo M. 2004. Glomerulonephritis and immunosuppression associated with a dietary essential fatty acid deficiency in gilthead sea bream, Sparus aurata L., juveniles. Journal of Fish Diseases 2004; 27: 297-6.

- Mu, H., Shen, H., Liu, J., Xie, F., Zhang, W. and Mai, K., 2018. High level of dietary soybean oil depresses the growth and antioxidative capacity and induces inflammatory response in large yellow croaker Larimichthyscrocea. Fish \& shellfish immunology, 77, pp.465-473.

- Ng, W.K., P.K. Lim, and H. Sidek. 2001. The influence of a dietary lipid source on growth, muscle fatty acid composition and erythrocyte osmotic fragility of hybrid tilapia. Fish Physiology and Biochemistry. 25:301-310.

- National Research Council 2011. Nutrient requirements of fish and shrimp. National Academies Press, Washington. 
- Peng, X., Li, F., Lin, S. and Chen, Y., 2016. Effects of total replacement of fish oil on growth performance, lipid metabolism and antioxidant capacity in tilapia (Oreochromisniloticus). Aquaculture international, 24(1), pp.145-156.

- Reitman, S. and Frankel, S., 1957. A colorimetric method for the determination of serum glutamic oxalacetic and glutamic pyruvic transaminases. American journal of clinical pathology, 28 (1), pp. 56-63.

- Riera-Heredia, N., Lutfi, E., Gutiérrez, J., Navarro, I. and Capilla, E., 2019. Fatty acids from fish or vegetable oils promote the adipogenic fate of mesenchymal stem cells derived from gilthead sea bream bone potentially through different pathways. PloS one, 14 (4), p.e0215926.

- Schalm, O.W. (1986). Veterinary Hematology. $4^{\text {th }}$ Ed., Lea, and Febiger, Philadeiphia.

- SPSS, 2004. Statistical and package for social science, SPSS for windows release14.0.0, 19 June 2004." The standard version, copyright SPSS Inc., 1989- 2004.

- Szabo, A., Mezes M, Hancz C, Molnar T, Varga D, Romvari R, Febel H., 2011. Incorporation dynamics of dietary vegetable oil fatty acids into the triacylglycerols and phospholipids of tilapia (Oreochromis niloticus) tissues (fillet, liver, visceral fat and gonads). Aquaculture Nutrition 17: 132-47. 
- Tietz, $N$ W., 1995. Clinical guide to laboratory tests, WB Saunders Co.

- Turchini G, Torstensen B, Ng W., 2009. Fish oil replacement in finfish nutrition. Reviews in Aquaculture 1:10-57.

- Villeneuve L, Gisbert E, Le Delliou H, Cahu C, ZamboninoInfante J., 2006. Intake of high levels of vitamin A and polyunsaturated fatty acids during different developmental periods modifies the expression of morphogenesis genes in European sea bass (Dicentrachus labax). Br J Nutrition; 95: 677-87.

- Watkins B, Li Y, Lippman H, Seifert M., 2001. Omega-3 polyunsaturated fatty acids and skeletal health. ExpBiol Med; 226:485-97. 